\title{
Potential Lignin Degraders Isolated from the Gut of Rhynchophorus Ferrugineus
}

\author{
Angzzas Sari Mohd Kassim, a Nadiah Ishak, b, Ashuvila Mohd Aripin ${ }^{1, c}$, \\ Dayang Norul Fairuz Abang Zaidel ${ }^{2, d}$
}

\author{
${ }^{1}$ Department of Chemical Engineering Technology, Faculty of Engineering Technology, \\ University of Tun Hussein Onn Malaysia (UTHM), 86400 Batu Pahat, Johor, Malaysia \\ ${ }^{2}$ Department of Bioprocess Engineering, Faculty of Chemical Engineering, \\ University of Technology Malaysia (UTM), 81310 Skudai, Johor, Malaysia. \\ aangzzas@uthm.edu.my, ${ }^{b}$ nadiah.ishak89@gmail.com, ${ }^{c}$ ashuvila.aripin87@gmail.com, \\ dayang@cheme.utm.my
}

Keywords: Wood-feeding insects, Lignin, Lignin peroxidase, Manganese peroxidase and laccase

\begin{abstract}
In industrial processes large amount of cost and pollution produced are derived from the process of removing lignin (delignification) to make high-quality paper through the chemical pulping process. Rynchophorus ferrugineus are wood-feeding insect that have the capacity to degrade wide range of lignocellulosic materials. Within this insect, the gut microbiomes play a major role in degrading lignocellulosic materials efficiently. The purpose of this research is to identify potential bacterial gut that could degrade lignin compound. R. ferrugineus larvae were dissected and the gut microbiomes were isolated. The bacteria were cultured in minimal salt media (MSM) with $0.5 \%$ lignin as sole carbon source. With this selective media, bacteria with lignin ability were cultured. Fifteen colonies were selected for species identification via 16S rRNA sequencing using universal primers $518 \mathrm{~F} / 800 \mathrm{R}$ which targets on $16 \mathrm{~S}$ gene. The capacities of individual species to produce ligninase were observed via enzyme activity assay. The results revealed four different types of species with lignin degrading ability that reside within the gut which are Enterobacter sp., Serratia sp. and Pseudomonas sp.. The ability of these bacteria in degrading lignin compound holds huge potentials which are useful for various applications such as bio-pulping, bioremediation and biofuel.
\end{abstract}

\section{Introduction}

Lignin is a complex phenylpropanoid polymer presence between the cell-wall of plant cells. This structural component is an important in plant as they provide physical strength imparting stiffness to the plant cells that enabling the plant to transport water and solutes through the tracheary elements in plant vasculature system [1]. However, lignin is recalcitrant to degradation thus is a major problem not only for pulping and paper making but also a problem in cattle feedstock and biofuel liquid production. In fact, in industrial process large amount of the cost and pollution produced are derive from the removal of lignin from wood to make high-quality paper [2]. Similarly, the amount of digestible energy available to ruminant livestock from fermentation of cell-wall polysaccharides is restricted by lignin, rendering much of the cellulose and hemicellulose inaccessible to rumen microorganisms [3].

Naturally, lignin is either degrade or modify by an enzyme known as ligninase which are produce by fungi or bacteria whether in soil or in the gut of wood feeding insects [4]. Microbial peroxidases enzymes such as lignin peroxidase, manganese peroxidase, dye- decolourizing peroxidase and laccases are essential in biodegradation of lignocellulosic materials within the guts of wood feeding insects [5]. R. ferrugineus has been widely known as major pest in wide range of palm trees such as oil palm, date palm and sago tree across Asian regions [6-8]. This is due to their ability to consume large amount of the plant tissues and results in the death of the infected tree within 6 to 8 months $[9,10]$. This wood-feeding insect lived on carbohydrate-rich diet which is 
wood and is dependent on the ability to degrade lignocellulosic compound for their survival [11]. Within the insects, gut microbiomes play a major role in ensuring lignocellulosic materials are efficiently degraded [4, 12]. Study of insects gut microbiomes provide an insight of digestive enzymes that possibly involve in lignin degradation or modifications. This study aims to identify potential bacteria that could degrade lignin from the gut of our tropical wood feeding insects, $R$. ferrugineus.

\section{Materials and Methods}

Samples Collection. $R$. ferrugineus larvae were collected within sago rumbia tree trunk (Metroxylonsagu) from a farm located in Parit Sulong, Batu Pahat. Before dissecting the insects, the size of adults' insects were measured. The larvae were surface sterilized with $70 \%$ ethanol and dissected with sterile fine forceps and micro-scissors in a petri dish. The guts were transferred into a $50 \mathrm{~mL}$ sterile centrifuge tube contained saline buffer $(0.8 \% \mathrm{NaCl}[\mathrm{pH} 7.5])$. Then, the guts were crushed inside the tubes to release the gut microbial.

Lignin Preparation. Lignin compound were extracted from non-wood source; cogon grass and palm oil leaves according to TAPPI (Technical Association Pulp and Paper Industry) standard method T $264 \mathrm{~cm}-97$ and T $222 \mathrm{om}-02$. The insoluble lignin compound was converted into fined particle size by using Planetary Ball Mills grinder at $350 \mathrm{rpm}$ for 5 minutes. The light brown color lignin was autoclaved at $120^{\circ} \mathrm{C}$ for 20 minutes.

Isolation of Lignin Degrading Bacteria. The gut bacteria were enriched in nutrient media before treated into minimal salt media- lignin (MSM-Lignin). Preparation of MSM-Lignin media broth: $200 \mathrm{ml}$ M9 Salt solution (64g Na $2 \mathrm{HPO}_{4} .7 \mathrm{H}_{2} 0,15 \mathrm{~g} \mathrm{KHPO} 4.7 \mathrm{H}_{2} 0,2.5 \mathrm{~g} \mathrm{NaCl}, 5.0 \mathrm{~g} \mathrm{NH} 4 \mathrm{Cl}, 1 \mathrm{~L} \mathrm{ddH}_{2} 0$ ), $2 \mathrm{ml} 1 \mathrm{M} \mathrm{MgSO}_{4}, 100 \mathrm{uL} 1 \mathrm{M} \mathrm{CaCl}, 5 \mathrm{~g}$ of extracted lignin powder, $1 \mathrm{~L}$ of $\mathrm{ddH}_{2} \mathrm{O}$ and were autoclaved at $120^{\circ} \mathrm{C}$ for 20 minutes. Preparation of MSM-Lignin Agar: $200 \mathrm{ml} \mathrm{M9}$ Salt solution, 2ml 1M $\mathrm{MgSO}_{4}, 100 \mathrm{uL} 1 \mathrm{M} \mathrm{CaCl}, 5 \mathrm{~g}$ of extracted lignin powder, $20 \mathrm{~g}$ of agar powder, $1 \mathrm{~L}$ of $\mathrm{ddH}_{2} \mathrm{O}$ and were autoclaved at $120^{\circ} \mathrm{C}$ for 20 minutes. $1 \mathrm{ml}$ from enrich bacterial culture in nutrient media were added into $100 \mathrm{ml}$ MSM-Lignin media and cultured for 7 days. Bacteria were plated on MSM-Lignin agar for colonies formation with lignin degrading ability selection.

Amplification and Sequencing of 16S rRNA. The 16S rRNA gene amplification and sequencing were carried out by First Base Laboratory, Malaysia. PCR was performed as following: $1 \mu \mathrm{L}$ of extracted gDNA was mixed with $20 \mu \mathrm{L}$ of PCR reaction mixtures and $27 \mathrm{~F} / 1492 \mathrm{R}$ primers pair $(27 \mathrm{~F}$ : 5'-AGA GTT TGA TCM TGG CTC AG-3', 1492R: 5'-TAC GGY TAC CTT GTT ACG ACT T-3'). The PCR reactions were carried out at $94^{\circ} \mathrm{C}$ for $45 \mathrm{sec}, 55^{\circ} \mathrm{C}$ for $60 \mathrm{sec}$ and $72^{\circ} \mathrm{C}$ for $60 \mathrm{sec}$ for 35 cycles. The purified PCR products of approximately $1,400 \mathrm{bp}$ were sequenced using $518 \mathrm{~F} / 800 \mathrm{R}$ primers pair (518F: 5'-CCA GCA GCC GCG GTA ATA CG-3', 800R: 5'-TAC CAG GGT ATC TAA TCC-3'). The PCR products were sequenced using Sanger sequencing method.

Sequences Analysis. All sequences were blasted using BLAST against the NCBI 16S ribosomal RNA sequences (Bacteria only) Database, excluding uncultured Bacteria bacterium (taxid: 77133). Sequences and their closest relatives were used to construct a phylogenetic tree.

\section{Results and Discussions}

Species Barcoding. The larvae were dissected and the guts were isolated (as in Fig. 1) in order to get access to the microbes with the potential of lignin degrading. Lignin was used as sole carbon source in the media that was used without addition of any glucose or other carbon sources. Only bacteria with the ability to degrade and utilize lignin as carbon source were able to survive. Fifteen colonies were selected on MSM-Lignin plate agar for further species identifications.

For 16S rRNA barcoding species, the genomics DNA of selected fifteen colonies were extracted and PCR reactions were conducted to amplify the 16S rRNA gene. The PCR reactions had selectively amplified the 16S rRNA gene and clean PCR products were obtained as shown in Fig. 2. Later, the PCR products were sequenced using Sanger method to give the full sequence of individual 16S rRNA gene. With the obtained sequences, each individual colony was identified 
using BLAST search databases. From the selected fifteen colonies, four bacteria species were redundantly identified. The species were identified as Klebsiella $s p$, Enterobacter $s p$, Serratia $s p$ and Pseudomonas sp. The 16S rRNA gene sequence of the isolates revealed that isolates RFG 1, RFG 4, RFG 13 and RFG 14 are sharing the homologies and closely related to genera of Klebsiella sp. Five isolates which are RFG 7, RFG 8, RFG 10, RFG 11 and RFG 12 were identified as Enterobacter sp.. Isolates RFG 2, RFG 3 and RFG 5 were identified as Pseudomonas sp. One isolates, RFG15 was identified as Serratia marcescens. Unfortunately, RFG 6 and RFG 9 were unable to be identified.

(a)

(b)

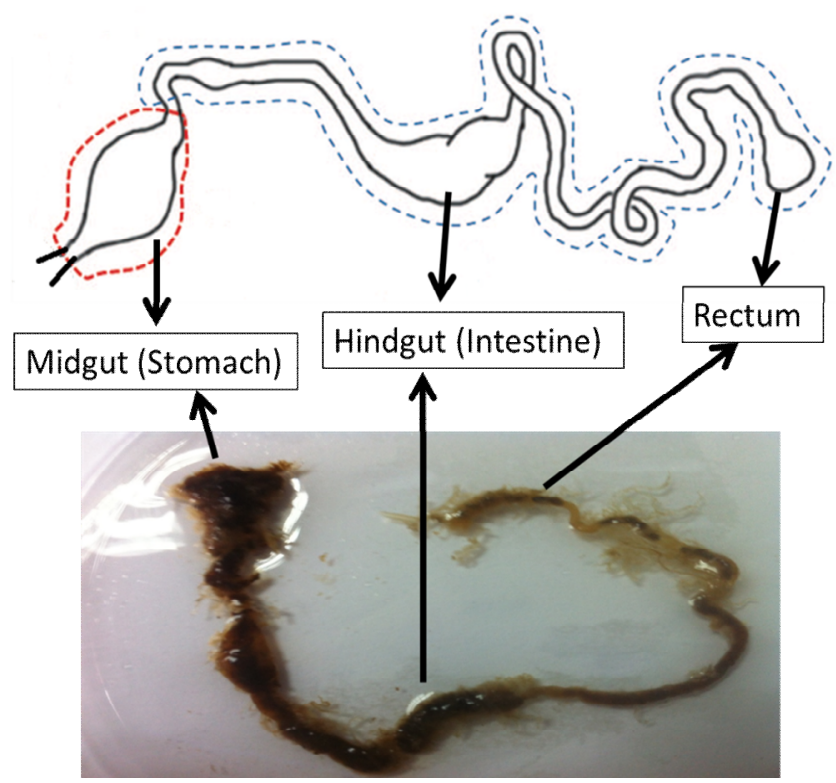

Fig. 1 Isolated gut from $R$. ferrugineus (Coleoptera: Curculionidae) larvae. The gut consist three compartments which include midgut (Stomach), hindgut (intestine) and rectum.

(a) A schematic diagram of R. ferrugineus gut from Darvishzadeh et al., [2012].

(b) Isolated $R$. ferrugineus larvae's gut.

\section{Identification of Lignin Degrading Bacteria}

$R$. ferrugineus larvae gut rich with microbes that are potentially expressing various enzymes related to lignocellulosic degradation. In this research, four major bacteria species that involved in lignin degradation were identified as Klebsiella sp, Enterobacter sp, Serratia sp and Pseudomonas $s p$. The gut microbial diversity exhibit how each of these endogenous bacteria act synergistically with each other to achieve efficient lignocellulosic degradation within the gut which by are essential for the survival.

Klebsiella sp. Klebsiella sp. is a gammaproteobacteria family of entrobacteriacacae. Klebsiella sp. have known disseminated in nature not only as microflora in the gut but also in the soil and water $[13,14]$.This result is consistent with the finding of pyrosequencing $R$. ferrugineus gut microbiota by Tagliavia et al., [15] which revealed the presence of $20.45 \%$ Klebsiella sp. from the total of gammaproteobacteria within the gut. Not only that, Klebsiella sp. have been reported to be isolated within the alimentary tract of asian longhorned beetle [16] and wood-boring beetle [17]. According to Doolittle et al., [18], Klebsiella sp.was also have been isolated from the hindgut of Formosan subterranean termites (Coptotermus formosanus). The presences of Klebsiella sp. in many guts of wood feeding insects are seemed to have an important role in lignocellulosic degradation. Complete genome sequence of Klebsiella sp. strain BRL-6 by Woo et al., [19] discovered four putative peroxidases including glutathione and DyP-type peroxidases that are related to the capability of Klebsiella $s p$ to degrade lignin in anaerobic conditions. 


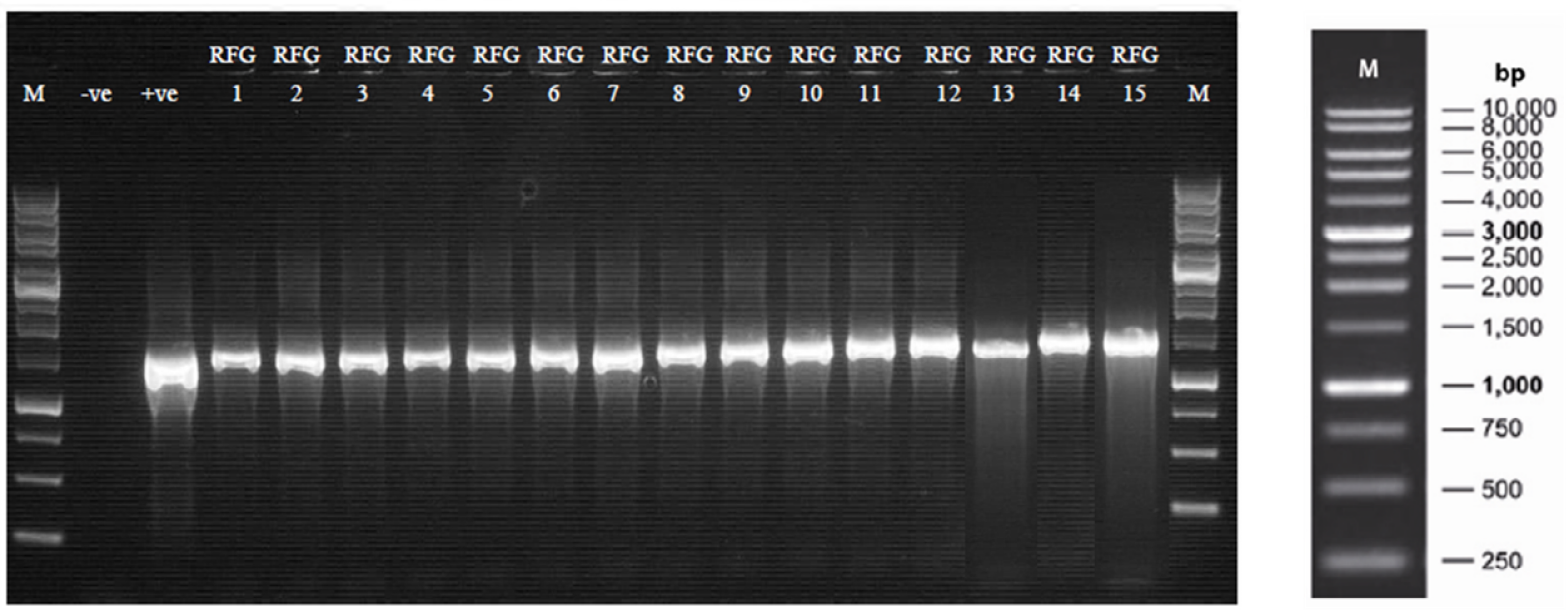

Fig. 2 Agarose gel electrophoresis of PCR products. The 16s rRNA gene were amplified using 27F/1492R primers pair. The band sizes were estimated around $\sim 1400 \mathrm{bp}$.

Therefore, Klebsiella $s p$. is able to survive using lignin as sole carbon source in culture media. And these approve that Klebsiella sp. as good lignin degraders with high potential of ligninase activity.

Enterobacter sp. Enterobacter sp. are from the family of enterobacteriaceae [20]. Enterobacter sp. can be found within the soil and known to play role in promoting root and shoot growth in many plant species [20-22]. On the other hand, these bacteria also are found to be associated with the wilt disease in banana plant [23]. Interestingly, there are not many literatures mentioned about the potential of Enterobacter sp. to degrade lignin even though full genome sequence of Enterobacter or Enterobacter radicincitans [24] have reported several Dyp-type peroxidases and laccases which related to lignin degradation. It could be that the Enterobacter $s p$. isolated from the gut of $R$. ferrugineus are novel lignolytic bacteria with good potential of being lignin degraders.

Serratia sp. Previously, the Serratia sp. have been characterized and optimized for potential bacterial strains for kraft lignin degradation during bleaching process by Morii et al., [25] This is because lignin is responsible for the brownish effect of the paper [26]. The ability of Serratia sp. to degrade lignin are well studied in the species of Serratia marcescens [27, 28]. The S. marcescens are able to decolourize ranges of synthetic aromatic dyes by peroxidases such as manganese peroxidase and dyp-type peroxidase [29, 30]. Recently, a psychrotolerant strain of $S$. marcescens (MTCC 4822) isolated from a glacial site shown to produce laccase at wide temperature and $\mathrm{pH}$ range [31]. Undoubtedly, the reason why Serratia $s p$. important in the gut of $R$. ferrugineus is mainly due to the capacity of these bacteria to secret ligninase enzyme that is responsible for lignin degradation.

Pseudomonas sp. Wide ranges of Pseudomonas sp. have been reported to have the ability to degrade lignin such as P. putida (Hoegger et al., 2006; Y. Wang et al., 2013), P aeruginosa [33], [34], P. fluorescence and many others. The occurrence of Pseudomonas sp. have been described in wood feeding insects such as in termites intestine [8] as well as in R. ferrugineus [35]. Bholay et al., (2012) screened lignolytic activity of $P$. aeruginosa for lignin peroxidase and manganese peroxidase whereby both enzymes are involved in lignin degradation. Nevertheless, the survival of Pseudomonas sp. on sole lignin source proved the ability of this species to degrade lignin.

\section{Conclusion}

The gut microbial of $\mathrm{R}$. ferrugineus does have important function involving lignin degradation. This is because the degradation of lignocellulosic compound is thought to be vital for survival. Four major species that have the capacity to degrade lignin have been isolated and identified as Klebsiella sp., Enterobacter sp., Serratia sp., and Pseudomonas sp. The main reason behind their survival in sole lignin carbon source media was due the ability to use lignin. There are possibility that these species do possess an enzyme such as peroxidase and laccase that could degrade or 
modify lignin. Such enzymes can be applied into various industrial biotechnology applications especially biofuel and pulping.

\section{Acknowledgement}

This research was financially supported by a scholarship from MyBrain15 and FRGS Grant (1506), Ministry of Education. The authors are thankful for this financial support.

\section{References}

[1] C. Pothiraj, P. Kanmani, P. Balaji, Potential bioproducts and their applications : Biomass Production of extracellular enzymes by fungi, Extensive, 34(4) (2006) 159-165.

[2] E. Novaes, M. Kirst, V. Chiang, H. Winter-Sederoff, R. Sederoff, Lignin and biomass: a negative correlation for wood formation and lignin content in trees, Plant Physiol. 154(2) (2010) $555-561$.

[3] C. Fu, J. R. Mielenz, X. Xiao, Y. Ge, C. Y. Hamilton, M. Rodriguez, Genetic manipulation of lignin reduces recalcitrance and improves ethanol production from switchgrass, 108(9) (2011) 3803-3808.

[4] T. D. H. Bugg, M. Ahmad, E. M. Hardiman, R. Singh, The emerging role for bacteria in lignin degradation and bio-product formation, Curr. Opin. Biotechnol. 22(3) (2011) 394-400.

[5] S. M. Geib, T. R. Filley, P. G. Hatcher, K. Hoover, J. E. Carlson, M. D. M. Jimenez-Gasco, A. Nakagawa-Izumi, R. L. Sleighter, M. Tien, Lignin degradation in wood-feeding insects, Proc. Natl. Acad. Sci. U. S. A. 105(35) (2008) 12932-12937.

[6] F. Abe, K. Hata, K. Sone, Life History of the Red Palm Weevil, Rhynchophorus ferrugineus ( Coleoptera : Dryophtoridae ), in Southern Japan, 92(3) (2009) 421-425.

[7] A. Darvishzadeh, A. R. Bandani, J. Karimi, Archives Of Phytopathology And Plant Protection Biochemical characterisation of digestive $\alpha$-amylase of Red Palm Weevil, Rhynchophorus ferrugineus (Olivier, 1790) (Coleoptera: Curculionidae), no. October 2013, pp. 37-41, 2012.

[8] M. Khiyami, E. Alyamani, Aerobic and facultative anaerobic bacteria from gut of red palm weevil (Rhynchophorus ferrugineus), 7(10) (2008) 1432-1437.

[9] R. El-Mergawy, A. Al-Ajlan, Red Palm Weevil, Rhynchophorus ferrugineus (Olivier): Economic Importance, Biology, Biogeography and Integrated Pest Management, 1 (2011) 1-23.

[10]Y. Wang, Q. Liu, L. Yan, Y. Gao, Y. Wang, W. Wang, A novel lignin degradation bacterial consortium for efficient pulping, Bioresour. Technol. 139 (2013) 113-119.

[11]F. J. Alarcon, T. F. Martınez, P. Barranco, T. Cabello, M. Diaz, F. Moyano, Digestive proteases during development of larvae of red palm weevil (Rhynchophorus Curculionidae). Digestive proteases during development of larvae of red palm, (2015).

[12]T. Köhler, C. Dietrich, R. H. Scheffrahn, A. Brune, High-resolution analysis of gut environment and bacterial microbiota reveals functional compartmentation of the gut in wood-feeding higher termites (Nasutitermes spp.), Appl. Environ. Microbiol. 78(13) (2012) 4691-4701.

[13]H. A. Ogot, H. I. Boga, N. Budambula, M. Tsanuo, and D. O. Andika, Isolation, characterization and identification of Diazinon degrading bacteria from the soil and gut of macrotermes, 3(9) (2013) 70-79. 
[14]K. Parthasarathi, L. S. Ranganathan, V. Anandi, J. Zeyer, Diversity of microflora in the gut and casts of tropical composting earthworms reared on different substrates, J. Environ. Biol. 28 (2007) 87-97.

[15]M. Tagliavia, E. Messina, B. Manachini, S. Cappello, P. Quatrini, The gut microbiota of larvae of Rhynchophorus ferrugineus Oliver (Coleoptera: Curculionidae). BMC Microbiol. 14(1) (2014) 136.

[16]J. D. Podgwaite, V. D’Amico, R. T. Zerillo, H. Schoenfeldt, Bacteria Associated with Larvae and Adults of the Asian Longhorned Beetle (Coleoptera: Cerambycidae), J. Entomol. Sci. 48(2) (2013) 128-138.

[17]A. Rizzi, E. Crotti, L. Borruso, C. Jucker, D. Lupi, M. Colombo, D. Daffonchio, Characterization of the bacterial community associated with larvae and adults of anoplophora chinensis collected in Italy by culture and culture-independent methods, Biomed Res. Int. 2013.

[18]M. Doolittle, A. Raina, A. Lax, R. Boopathy, Presence of nitrogen fixing Klebsiella pneumoniae in the gut of the Formosan subterranean termite (Coptotermes formosanus), Bioresour. Technol. 99 (2008) 3297-3300.

[19]H. L. Woo, N. R. Ballor, T. C. Hazen, J. L. Fortney, B. Simmons, K. Davenport, L. Goodwin, N. Ivanova, N. C. Kyrpides, K. Mavromatis, T. Woyke, J. Jansson, J. Kimbrel, K. M. DeAngelis, Complete genome sequence of the lignin-degrading bacterium Klebsiella sp. strain BRL6-2, Stand. Genomic Sci. 9(1) (2014) 19.

[20]P. Kämpfer, S. Ruppel, R. Remus, Enterobacter radicincitans sp. nov., a plant growth promoting species of the family Enterobacteriaceae, Syst. Appl. Microbiol. 28 (2005) 213-221.

[21]A. K. Brock, B. Berger, I. Mewis, S. Ruppel, Impact of the PGPB Enterobacter radicincitans DSM 16656 on Growth, Glucosinolate Profile, and Immune Responses of Arabidopsis thaliana, Microb. Ecol. 65(3) (2013) 661-670.

[22]S. Hill, V. M. Bergottini, S. Filippidou, T. Junier, Genome Sequence of Kosakonia radicincitans Strain YD4, a Plant Growth-Promoting Rhizobacterium Isolated from Yerba Mate Ilex, 3(2) (2015) 6964.

[23]N. S. Mohd Suhaimi, K. P. Yap, N. Ajam, and K. L. Thong, Genome sequence of Kosakonia radicincitans UMEnt01/12, a bacterium associated with bacterial wilt diseased banana plant, FEMS Microbiol. Lett. 358(1) (2014) 11-13.

[24]K. Witzel, M. Gwinn-Giglio, S. Nadendla, K. Shefchek, S. Ruppel, Genome sequence of Enterobacter radicincitans DSM16656T, a plant growth-promoting endophyte, J. Bacteriol. 194(19) (2012) 5469-5469.

[25]H. Morii, K. Nakamiya, S. Kinoshita, Isolation of a Lignin-Decolorizing Bacterium, 80(3) (1995) 296-299.

[26]L. Sahadevan, C. Misra, V. Thankamani, Ligninolytic Enzymes for Application in Treatment of Effluent from Pulp and Paper Industries. Univers. J. Environ. Res. Technol. 3(1) (2013) 14-26.

[27]Y. Wang, Q. Liu, L. Yan, Y. Gao, Y. Wang, W. Wang, A novel lignin degradation bacterial consortium for efficient pulping, Bioresour. Technol. 139 (2013) 113-119.

[28]H. Abd-Elsalam, A. El-Hanafy, Lignin biodegradation with ligninolytic bacterial strain and comparison of Bacillus subtilis and Bacillus sp. isolated from Egyptian soil, Am Eurasian J. Agric. Env. Sci. 5(1) (2009) 39-44.

[29]P. Verma, D. Madamwar, Decolourization of synthetic dyes by a newly isolated strain of Serratia marcescens, 19(6) (2003) 615-618. 
[30]F. Perestelo, Biotransformation of kraft lignin fractions by Serratia marcescens, Lett. Appl. Microbiol. 10(2) (1990) 61-64.

[31]G. S. Kaira, K. Dhakar, A. Pandey, A psychrotolerant strain of Serratia marcescens (MTCC 4822) produces laccase at wide temperature and pH range, AMB Express, 5(1) (2015) 1-8.

[32]P. J. Hoegger, S. Kilaru, T. Y. James, J. R. Thacker, U. Kües, Phylogenetic comparison and classification of laccase and related multicopper oxidase protein sequences, FEBS J. 273(10) (2006) 2308-2326.

[33]K. G. Welinder, Superfamily of plant, fungal and bacterial peroxidases, Curr. Opin. Struct. Biol. 2(3) (1992) 388-393.

[34]A. D. Bholay, V. Borkhataria Bhavna, U. Jadhav Priyanka, S. Palekar Kaveri, V. Dhalkari Mayuri, P. M. Nalawade, Bacterial Lignin Peroxidase: A Tool for Biobleaching and Biodegradation of Industrial Effluents, Univ. J. Envir. Res. Technol. 2(1) (2012) 58-64.

[35]S. Jia, X. Zhang, G. Zhang, A. Yin, S. Zhang, F. Li, L. Wang, D. Zhao, Q. Yun, Tala, J. Wang, G. Sun, M. Baabdullah, X. Yu, S. Hu, I. S. Al-Mssallem, J. Yu, Seasonally variable intestinal metagenomes of the red palm weevil (Rhynchophorus ferrugineus). Environ. Microbiol. 15(11) (2013) 3020-3029. 